\title{
HAPPINESS VS SECURITY: BACKGROUND AND CONSEQUENCES
}

In Happiness And Contemporary Society : Conference Proceedings Volume (Lviv, March, 20-21, 2021). Lviv: SPOLOM, 2021. P. 164-167. https://doi.org/10.31108/7.2021.37

ISBN 978-966-919-697-2

\section{ЩАСТЯ VS БЕЗПЕКА: ПЕРЕДУМОВИ І НАСЛІДКИ}

// Щастя та сучасне суспільство : збірник матеріалів міжнародної наукової конференції (Львів, 20-21 березня 2021 р.). - Львів : СПОЛОМ, 2021. С. 164-167. https://doi.org/10.31108/7.2021.37

ISBN 978-966-919-697-2 
https://doi.org/10.31108/7.2021.37

LIASHENKO Oleksandra

Doctor of Sciences in Economics, Full Professor

KROK University (Kyiv, Ukraine)

The Ukrainan Institute for Happiness Research

\title{
HAPPINESS VS SECURITY: BACKGROUND AND CONSEQUENCES
}

Security and happiness are integral parts of a whole: the level of happiness increases as security, while security is a prerequisite not only for the realization of human rights and freedoms but also (objectively) happy conditions of its existence. The connotation of the concept of "happiness" is constantly transformed, modernizing its multifaceted essence. The discourse of the concept of happiness penetrates into the multifaceted concept of security, which is fragile and vulnerable to numerous threats becomes one of the defining characteristics of happiness. The hierarchy of security meanings - from personal to global - forms numerous relationships with the axiological narrative of happiness, creating a favorable foundation for sustainable development. The relationship between the concepts of happiness and security is discussed. High social demand for happiness and security has been demonstrated. The interdependence and processes that affect the formation of happiness and security are outlined.

Keywords: happiness, security, vulnerability, relationship

\author{
ЛЯШЕНКО Олександра \\ доктор економічних наук, професор \\ ВНЗ «Університет економіки та права «КРОК» (Київ, Украӥна) \\ Украйнський інститут дослідження щастя
}

\section{ЩАСТЯ VS БЕЗПЕКА: ПЕРЕДУМОВИ І НАСЛІДКИ}

Конотація поняття «щастя» невпинно трансформується, модернізуючи його мультиаспектну сутність. У свою чергу, дискурс цього поняття дедалі більше конвергує до не менш мультиаспектного поняття безпеки, яка у часи крихкого та уразливого до численних загроз світоустрою стає однією 3 визначальних характеристик щастя. Ієрархія сенсів безпеки - від особистої до глобальної - утворює численні взаємозв'язки з аксіологічним наративом щастя, створюючи сприятливе підгрунтя для сталого розвитку. Здійснений авторкою точковий експрес-аналіз процесів, які характеризують розуміння понять «щастя» та «безпека» у соціокультурному просторі дає підстави для такого твердження (рис. 1).

Застосування аналітичної платформи Google Trends на річному часовому відтинку (березень 2020 лютий 2021 рр.) демонструє високий запит на майже синхронний запит безпекотворчих та щастятворчих чинників в Україні. Звісно, подальший пошук кореляційних зв'язків може бути двостороннім: визначення залежності рівня щастя від рівня безпеки і навпаки. До речі, це може бути предметом крос-дисциплінарних наукових розвідок.

Ще більше підстав для вивчення перетину щастя vs безпека дає порівняння скорочених трендів Світового індексу щастя та Глобального індексу безпеки (табл. 1). 


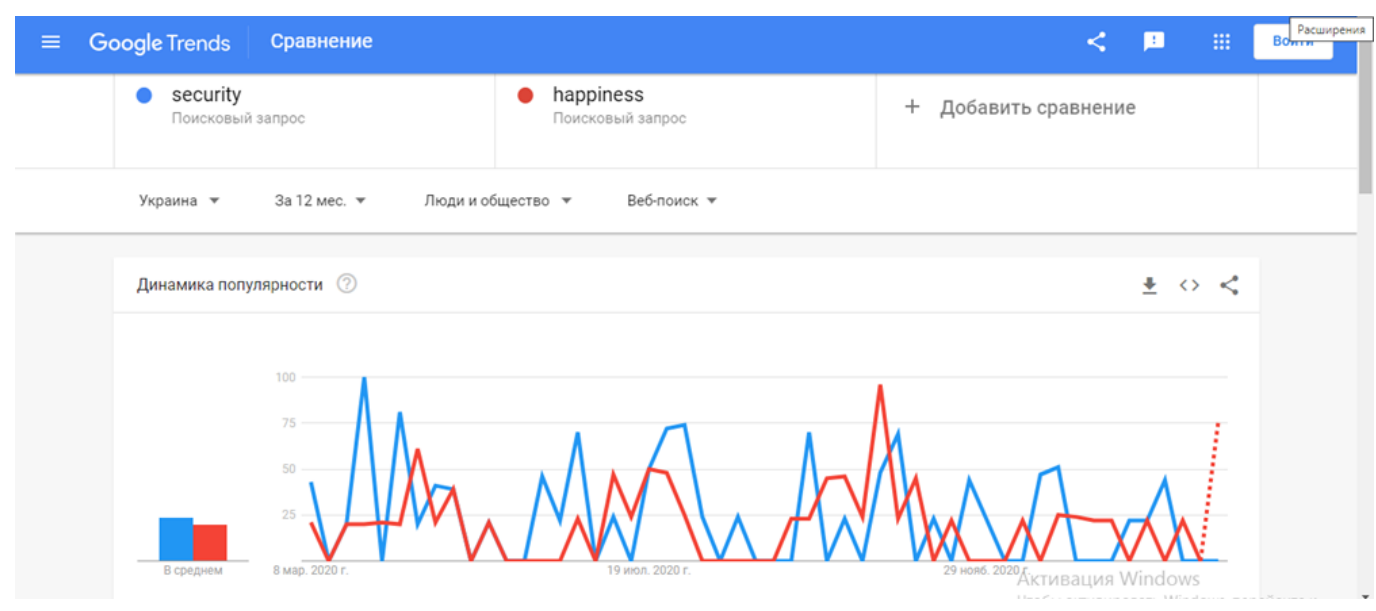

Рис. 1. Щастя vs безпека: порівняння частоти пошукових запитів (проаналізовано авторкою станом на 25.02.2021 р.)

Таблиця 1

Щастя vs безпека: порівняння рейтингів

\begin{tabular}{|c|c|c|c|c|c|c|}
\hline \multirow{3}{*}{ Країна } & \multicolumn{3}{|c|}{$\begin{array}{c}\text { Світовий індекс щастя } \\
\text { (Happy Planet Index за версією } \\
\text { New Economic Foundation) }\end{array}$} & \multicolumn{3}{|c|}{$\begin{array}{c}\text { Глобальний індекс миру } \\
\text { (Global Peace Index) }\end{array}$} \\
\cline { 2 - 7 } & 2010 p. & 2015 p. & 2020 p. & 2010 p. & 2015 p. & 2020 p. \\
\hline Україна & 87 & 111 & 123 & 97 & 150 & 148 \\
\hline
\end{tabular}

Складено авторкою за матеріалами $[1,2]$

Якщо Міжнародний індекс щастя грунтується на загальних утилітарних принципах, що більшість людей хочуть прожити довге і повноцінне життя, а країни прагнуть зробити все можливе для досягнення максимального добробуту своїх громадян, розумно використовуючи наявні ресурси, не завдаючи шкоди довкіллю і для розрахунку використовуються такі показники, як-от: суб'єктивна задоволеність життям людьми, очікувана тривалість життя i так званий «екологічний слід», то при складанні Глобального індексу миру враховуються 23 індикатори в трьох різних категоріях, включаючи "безпеку в суспільстві", "триваючі конфлікти" і "мілітаризацію". У першій категорії, зокрема, звертається увага на рівень вбивств, кількість ув'язнених, кількість поліцейських і сприйняття злочинності, в останній розглядалося число військовослужбовців, витрати на озброєння в співвідношенні до ВВП і експорт зброї. Однак, глибинна семантика сенсів цих індексів формує логічні пари залежностей: вплив рівня щастя на рівень безпеки і навпаки6 вплив рівня безпеки на рівень щастя.

Загальний «індекс щастя» українців у 2020 році становив 14\%. У 2019-му цей показник був майже вдвічі вищим і становив 33\%, а у 2018 був на рівні всього $8 \%\lceil 1\rceil$. В оновленому "Глобальному індексі миру" Україна все ще залишається серед переліку країн з низьким рівнем миру, займаючи підсумкове 148-е місце між Нігерією (147) та Венесуелою (149). Згідно звіту, Україна опинилася наприкінці списку "Глобального індексу миру" за 2020 рік - зайнявши 148-е підсумкове місце 
iз 163 можливих. "Сусідами" України по рейтингу виявилися Нігерія (147), Венесуела (149), Туреччина (150), Північна Корея (151) та Пакистан (152). При цьому, Україна зуміла "покращити" у порівнянні із попереднім роком одну позицію в індексі. Зазначається, що у порівнянні з минулим роком, індекс миру в регіоні "Росія та Євразія", до якого входить Україна, покращився, однак погіршення показників миру спостерігалися у Туркменістані, Казахстані і Україні. Також вказується, що Україна займає 27-е місце за економічною вартістю насильства, низькі позиції наша країна продемонструвала також у показнику мілітаризації та рівневі соціальної безпеки. Лідерами індексу стали: Ісландія (1), Нова Зеландія (2), Португалія (3), Австрія (4), Данія (5), Канада (6), Сінгапур (7), Чехія (8), Японія (9) і Швейцарія (10). Серед великих країн, то США зайняли низьке 121-е місце, Велика Британія - 42-е, Франція - 66 [2]. Порівняння наведених у табл. 2 трендів показує, що протягом останніх 10 років Україна суттєво погіршила своє розташуваня в обох рейтингах. Взаємозв'язок порівнюваних процесів і явищ дає підстави висунути гіпотезу: зниження рівня щастя робить суспільство більш уразливим до небезпек, а, отже, більш небезпечним. Водночас, вивищення небезпек або занепад безпеки у свою чергу призводить до зниження «градусу» щастя.

Чи досджувалися подібні залежності раніше? Вельми дотично і переважно 3 позиції кримінально-правового виміру, наприклад, у праці В. В. Щаблистого Ґ2ๆ, який, зокрема, зазначає наступне: «3 позиції кримінально-правового гарантування безпеки людини ... громадяни тих країн (або жителі таких міст), які відчувають себе більш щасливими порівняно з розвиненішими містами чи країнами, з часом утрачатимуть задоволеність своїм життям через неможливість задоволення своїх потреб». Далі автор розвиває тезу про те, що таке явище слугує цілям криміналізації суспільства, пояснюючи це тим, що «..головним у генезі насильства $\epsilon$ не сам по собі рівень задоволення потреб, а ступінь різниці в можливості їх задоволення для різних соціальних груп, оскільки заздрість, незадоволеність, розуміння самої можливості жити краще приходять лише у порівнянні». Отож, головним криміногенним фактором $\epsilon$ суперечність між потребами людей i реальними можливостями, що, своєю чергою, $\epsilon$ i передумовою, i наслідком зниження рівня щастя. Причому масштабованість такого явища як рівень щастя різко зростає до виміру суспільства в цілому за умови утиснення рівня персональної економічної безпеки, тобто збіднення населення.

Такі аргументи доводять, що безпека та щастя є невід'ємними частинами єдиного цілого: рівень щастя зростає по мірі убезпечення, тоді як безпека $\epsilon$ передумовою не лише реалізації прав і свобод людини, але і (об'єктивно) щасливих умов іiї існування.

$\mathrm{He}$ можна не проілюструвати наведені аргументи екзистенційними роздумами засновника охоронного холдингу «Шериф» Дмитра Стрижова [4], який зазначає: «одним з об'єднавчих факторів, що роблять безпечними для жителів країни з топа щасливих, $\epsilon$ профілактика безпеки - поширена практика забезпечення охорони майна і самих людей. У розвинених країнах не прийнято чекати небезпеки i відчувати над собою дамоклів меч, навпаки: будинки грамотно технічно обладнані і перебувають під пильним наглядом охорони, на все рухоме і нерухоме майно встановлені трекери і охоронні сигналізації, а в суспільстві дотримуються правил інформаційної гігієни». Автор також зазначає, що в Україні немає довіри до державних органів як в силу стереотипів і історично зумовленої упередженості, 
так і з урахуванням кричущих фактів злочинної недбалості, що все з'являються. Вкрай низький відсоток розкриття дрібних крадіжок i загальний обсяг бюрократичної тяганини, пов'язаний з будь-яким зверненням у правоохоронні органи, виховав філософське ставлення до майна і відстоювання своїх прав i свобод. Водночас, він зважає і на те, що культура убезпеки в Україні вже починає формуватися і зазначає, що безпека $є$ одним з необхідних елементів пазла цілком відчутного щастя.

$€$ ще один доволі цікавий аспект: якщо скромні вітчизняні згадування про взаємозалежність щастя і безпеки перебувають у площині так званого захисного підходу до безпекотворення, то поодинокі згадування про аналогічну залежність у зарубіжних публікаціях, наявних в інтернет-просторі, стосуються переважно психологічних процесів і духовних практик, та особистісного сприйняття. Інакше кажучи, елементи крос-культурних наративів також можуть стати окремою сферою соціо-гуманітарних досліджень щастя і безпеки.

Отже, вивчення взаємозв'язків дихотомії понять «щастя-нещастя» i «безпека-небезпека» може стати своєрідним плацдармом для довгого переліку нових крос дисциплінарних досліджень.

\section{ЛІТЕРАТУРА}

1. World Happiness Report https://worldhappiness.report

2. Global Peace Index https://www.visionofhumanity.org

3. Шаблистий В. В. Безпека людини як показник ії щастя (кримінально-правовий вимір) // Публічне право № 4 (12) (2013). - С. 122-126.

4. https://nv.ua/ukr/ukraine/events/shchastya-vimagaye-pevnogo-rivnya-osobistojibezpeki-i-zahistu-ekspert-50102061.html 